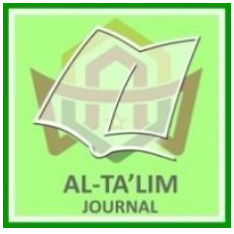

AL-TA'LIM JOURNAL, 26 (2), 2019, (147-159)

(Print ISSN 1410-7546 Online ISSN 2355-7893)

Available online at http://journal.tarbiyahiainib.ac.id/index.php/attalim

\title{
Constructing Social Attitudes and Religious Tolerance in Emerald Diversity through te Teaching of Religion and Cultural Values
}

\author{
Received: $03^{\text {th }}$ December 2018; Revised: $14^{\text {th }}$ May 2019; Accepted: $30^{\text {th }}$ July 2019 \\ Permalink/DOI: http: //dx.doi.org/10.15548/jt.v26i2.539
}

\section{Ilfiana Firzaq Arifin*) \\ Universitas Sebelas Maret Surakarta, Indonesia. \\ E-mail: ilfianafirzaq@gmail.com}

\begin{abstract}
Akhmad Arif Musaddad
Universitas Sebelas Maret Surakarta,

Indonesia.

E-mail: arif_mussadad_fkip@yahoo.co.id
\end{abstract}

\section{Sudiyanto}

Universitas Sebelas Maret Surakarta, Indonesia.

E-mail: soeddie.fkipuns@gmail.com

\section{*) Corresponding Author}

\begin{abstract}
Diversity is already common place in Indonesia as a country that is nicknamed as the Emerald diversity. Indonesian state decorate diversity is seen as something that is very unique, but foreigners do not know that it is actually in it churned a result of lack of tolerance. SMK Nurul Ulum is a school that is not wished for it to happen. Therefore, this school creates an attitude of tolerance among human beings, which is based on the teachings of Islam, Christianity, Hindu-Buddhist and Pendhalungan cultural values. The method used in this article is using qualitative descriptive analysis techniques and observation. Descriptive analysis is done by reviewing a wide range of journals, books, articles and other sources that support. While the observation conducted at SMK Nurul Ulum Jember namely by conducting in-depth interviews to the relevant school. The results showed that with the use of the teachings of tolerance of various religious and Pendhalungan cultural values and use a good strategy, tolerance can be built effectively in this school.
\end{abstract}

Keywords: Diversity; tolerance; religious teachings; cultural values

How to Cite: Arifin, I., Musaddad, A., \& Sudiyanto, S. (2019). Constructing social attitudes and religious tolerance in emerald diversity through the teaching of religion and cultural values. Al-Ta Lim Journal, 26(2). doi:http://dx.doi.org/10.15548/jt.v26i2.539

\section{INTRODUCTION}

Indonesia is a nation that is known tribes, culture, customs, language, and religious diversity. Thus, the unity in diversity that has a meaning different but still one nevertheless, be used as a slogan by this nation as a container and to accommodate differences in ethnicity, religion, culture, customs and other differences are there in the community of this nation. The diversity and plurality of ethnic, cultural, ethnic and other differences that exist in Indonesia is a difference that is difficult to find in any other world region. The islands that stretches from Sabang to Merauke, which account for more than 1000 islands signify the diversity of people who inhabit the region and multiple pattern of life they lead every day. This is what indicates that Indonesia is a diverse country and people.

Cultural diversity, ethnicity, religion, race and so forth illustrated like the stars in the sky were scattered like pearls decorate the universe. Calm and orderly as proclaim eternal peace to all living things on earth. But who thinks that tranquility and order an umbrella for the night is a mirage, because behind the orderly principle also applies denial law. Only a powerful force capable of forcing the stars settle and survive in orbit respectively. 
As described above, the Indonesian state does have an incredible diversity of variety and not shared by other countries in the world, so that unity in diversity serve as a motto for the state that was founded in 1945. However, the unity in diversity that was originally a heritage of harmony and tolerance among fellow citizens, then made in the political frame for particular interests. Implementation motto Unity in Diversity is not aimed to foster national unity but rather social exclusiveness and jealousy. So that it becomes the beginning of the emergence of SARA (ethnicity, religion, race and class), which was originally less in realized by the majority of the Indonesian people.

Strained and conflicts in Indonesia increasingly prevalent felt. Like the case of religious intolerance attacks against Christians in the Church of St. Lidwina Sleman, Yogyakarta on the Sunday, February 11, 2018 reported by the daily (IDNTimes, 2018), Said that there are social conflicts that religious horizontal social dissolution bazaar event conducted by some of the members of the church of St. Paul Pringgolayan Bantul, Yogyakarta and others. Interestingly, cases of intolerance against the Christian and Catholic religious adherents is done by the followers of Islam, so that it can be concluded that Indonesian Muslims are very minimal to have the soul of a great tolerance. Glancing at other cases that occurred in Indonesia, as reported in the daily (Kompas.com, 2018) Chapel in the case of refusal to appear Sukoharjo, Arqom mosque in the town of Pekalongan, refusal GKI Mojosongo in Jebres Solo and Colomadu Pentecostal Church envoy in Karanganyar. Problems of religious diversity as described above is an inevitable consequence (Turner, 2006), However, what's wrong if we as humans are intelligent and virtuous are either trying to avoid it for reasons of preservation of the integrity of the joint in the middle of a difference.

By looking at a wide range of events that was coloring the social life of people in Indonesia, whether it can be said that the Indonesian people have social tolerance attitude even high religious tolerance? Of course the answer is No. How not, the soul of humanity that should be in every public conscience today eroded and eroded by the roar of passion that enveloped the middle of them.

Many factors make the Indonesian people swabs do not have human brains and use them to behave, but they have and use an animal's brain to act. Whereas a few decades ago socialization that exists in the midst of a multi-cultural society like Indonesia have established very well. But over time, with the arrival of a new civilization, the increasingly sophisticated information technology and the growing science community to make Indonesia an open and accepting of civilization. It should be with the arrival of new things in the midst of their life, they should use it as well as possible for the survival and integrity. But quite the contrary, the Indonesian people do not use it to preserve the integrity, but to create a homogeneity which is not expected by the Indonesian state. Things like this can be seen from the community, the community initially seen as a heterogeneous, increasingly looks homogeneous. Such differences often lead to conflict and social class inequalities are increasingly evident. The increasingly dynamic society causes people begin to ferment and is not easily satisfied with what is on to get it. Is it possible that all of this is the impact of globalization which according to many was a byword in this third millennium? I do not know, only God omniscient all existing events of the earth's surface. increasingly looks homogeneous. Such differences often lead to conflict and social class inequalities are increasingly evident. The increasingly dynamic society causes people begin to ferment and is not easily satisfied with what is on to get it. Is it possible that all of this is the impact of globalization which according to many was a byword in this third millennium? I do not know, only God is omniscient all existing events of the earth's surface. increasingly looks homogeneous. Such differences often lead to conflict and social class inequalities are increasingly evident. The increasingly dynamic society causes people begin to 
ferment and is not easily satisfied with what is on to get it. Is it possible that all of this is the impact of globalization which according to many was a byword in this third millennium? I do not know, only God is omniscient all existing events of the earth's surface. Is it possible that all of this is the impact of globalization which according to many was a byword in this third millennium? I do not know, only God is omniscient all existing events of the earth's surface. Is it possible that all of this is the impact of globalization which according to many was a byword in this third millennium? I do not know, only God is omniscient all existing events of the earth's surface.

To be sure, with a view sad of situation is happening in the country of Indonesia today, there are schools that do not want to look and feel as perceived by the state body that runs in fragility, and emerging as Indonesia. that is SMK Nurul Ulum Jember. This school is a school that does not want to feel the bitterness of multicultural indeed adorn themselves in a large container, but ultimately failed, but this school want to feel the pleasure and sweetness of existing multicultural. The school is aware that he himself was present in the midst of a multicultural society and a forum for children's multicultural society to be together and live together is decorated with harmony. Therefore,

Tolerance built in this school is social tolerance and religious tolerance. Tolerance that the school is not tolerance poorly constructed and do not have a definite basis. However, tolerance is built by this school is tolerance based on cultural values and the religions. Cultural values adopted by the school to build an attitude of tolerance is of cultural value Pendhalungan, which is the original culture of the community Jember. While the religious values that form the basis of development of tolerance in SMK Nurul Ulum Jember is based on the value of the teachings of Islam and not a few others of the value of other religious teachings such as Christian, Hindu-Buddhist and so on.
The purpose of writing this article is to reveal and menggambarakan development of tolerance in vocational Nurul Ulum Jember, such as where the source of tolerance, the tolerance for what and by whom such tolerance exists. So from this particular article will be obtained new knowledge to build tolerance in the midst of such diversity emerald Indonesia.

\section{METHOD}

The method used in this article is using qualitative descriptive analysis techniques and observation. Descriptive analysis is done by reviewing a wide range of journals, books, articles and other sources that support. While the observation conducted at SMK Nurul Ulum Jember namely by conducting in-depth interviews to the school as headmaster named Mahrus Sadikin, S.Pd.I, the whole board of teachers, and students there are in school. Then interviews were also conducted on the surrounding community that is close to the school that received the impact of the establishment of vocational Nurul Ulum Jember.

\section{RESULT AND DISSCUSSION}

\section{Record Traces in Social Life Plus SMK Nurul Ulum}

Plus SMK Nurul Ulum is a private school that was founded in 2004. This school is located in the village school Kemungsarilor which is one subsidiary of Panti subdistrict Jember. SMK Nurul Ulum is a school that stands in Islamic boarding schools and foundations under the At-Tawheed Nurul Ulum under the care of KH. Hanief Abdul Razak and his wife Mrs. Aini. SMK Nurul Ulum is a private school which has a membership program that dressmaking. This school SMK 3 have its main office in Jember from 2004 to 2016 yesterday. While this time of enactment of the new regulations, the school finally have its main office in SMK 1 Jember but with the same expertise that program dressmaking.

SMK Nurul Ulum is a school that is located in boarding schools, but he remains 
the same school as other schools in Jember that schools that have students consisting of both men and women. They blend into one in the classroom, but they must observe the norms of boarding schools and schools that apply for example, forbidden to speak privately with no other friend for those opposite sex, not allowed to open the genitalia in front of his friends that the opposite sex and many other rules again. This school can be said that a multicultural school. Said to be multicultural because the school has an average student who comes from a variety of cultures, races, religions flow (historical background) different. The composition of such students can not be denied because they come from all over to remote villages, not only in the village of Panti subdistrict Kemungsarilor alone, but they came from other villages well within the scope of the sub-district and outside Panti Panti subdistrict. The incorporation of students in vocational Plus multikultrur Nurul Ulum heterogeneous led to the creation of life.

Heterogeneity almost contributed by $75 \%$ for vocational school Nurul Ulum. So that the male and female students who are in vocational Nurul Ulum consist of various tribes namely Java, Madura, Arabic and Chinese Muslims. From tribes there also spawned a wide variety of languages used by them everyday in school as well as language Indonesian Java and Madura. Then, with the existing heterogeneity so that being born too keagaamaan streams carried by each student as Muslim Nahdlatul Ulama, Muhammadiyah and Islam Islam Yahuk (Javanese).

Uuniqueness that adorn SMK Nurul Ulum as multiple agreed that adorn this nation that stretches from Sabang to Merauke. Thus, SMK Plus Nurul Ulum can also be referred to as a multi-cultural school or school Emerald Diversity.

It is true SMK Plus Nurul Ulum is a school composed of students who are multicultural, but rarely conflicts therein. Petty conflicts do exist but quickly resolved by deliberation and democratic way so as not reaching to the conflict at the macro level. In this case the teacher plays an important role so that the student can control its emotions in order not to translate them into social conflicts that are horizontal. So that every day teachers are required to constantly monitor the emotional development of students khsusnya guidance and counseling teachers. With the role of the teacher incredible, the conflict that sometimes carry the name of multiculturalism in SMK Plus Nurul Ulum rare. Harmony and peace always surrounds the school, with the invisibility of male and female students each other mutual help, joking with peers or teachers, respect brother tingat or sister level, respect for teachers as an older person, and so both when studying or when the recess starts. This warm asrinya circumstances make SMK Plus Nurul Ulum as schools that succeed in meembangun tolerance.

\section{How To View The Attitude Tolerances}

Attitude is a depiction of the process away from someone who responds to what he had learned. In this case also illustrates the attitude that a person can accept or reject to the obtainment. Attitude is usually raised when people interact to fellow social environment. Tolerance is one of the attitudes that exist in man which serves as a depiction of themselves against a response. Often we hear the phrase the words tolerance, good surrounding environment, in social media, electronic media, and other media, and even the words of tolerance is not foreign to our ears ringing. Tolerance is a word often spoken by many people. They usually say when they are faced with a problem that imbalance and harm others. Usually tolerance we often hear when someone talks about the difference, heterogeneity, multicultural, and the like.

In relation to plurality, in various aspects of life as experienced by the people of Indonesia in terms of culture, race, ethnicity, religion and so on, tolerance is of great influence on the survival of human life. Tolerance is considered as a provision that should be there and always be placed in the leading position in the act to deal with the differences in order to avoid discriminatory attitudes, alienation and even against the condescension of others. So that the position in which tolerance is very important to the 
lives of people especially people who have a heterogeneous life. It is so importance of tolerance for mankind, so many characters that define the term tolerance in his writings in a variety of books, articles imiah, journals,

The term tolerance if we learn from history is derived from the English "tolerantion". While the meaning of the most classic that appears in the 16th century the "Toleration" which means a permit granted by the authority / license. Meanwhile, approximately in 1689 said it has the feel of interfaith relations because there is a law of tolerance. In the body of the agreement was explained that the guarantee of freedom of religion and worship to the Protestant group in the UK. Because at that time frequent violations and restrictions on the belief that the result of conflict between Catholics and Protestants in Europe (Simarmata, 2017),

Turnbull et al., (2010) in the Oxford Advanced Learners Dictionary of Current English say that tolerance is the attitude of allowing, recognizing and respecting the beliefs of others without requiring approval. While Almond (2010) said that "I think that most of the time what we have in mind when we speak of tolerance is something closer to 'acceptance' or even 'celebration". He said that tolerance is an attitude that is close to the acceptance or celebrate something although not in accordance with the will of conscience. Acceptance implies consent, while implying enthusiastic celebration to perform an activity. In line with the opinion of the two figures above, (Powell, 2002) also stated that an attitude of tollerance is only possible when some action or practice is objectionable to us, but we have ovveriding reasons to allow that action or practice to take place. The statement implied that tolerance is an exception to things that are not favored, but still left to do.

Fiala (2005) considers that tolerance can be interpreted as a necessity in the individual rooms and public spaces, because one of the goals is to build a peaceful life tolerance among the various differences in historical background, culture and identity. This was in line with the principle of SMK Plus Nurul Ulum in building an attitude of tolerance which is to preserve the unity amid differences. In line with these opinions, (Endang, 2009) define tolerance is actually an attitude that developed within the framework of their diversity in various dimensions of life, so that will come into harmony and harmony of life, far from conflicts and social tensions, even more antagonism and hostility between each other in the community.

Witenberg (2007) defines tolerance as a conscious act of self to others involving humanitarian principles that the principles of fairness, respect, equality (race, ethnicity and nationality). Meanwhile, according to Williams (2015) defines tolerance as an attitude of respect for human rights. Of the many opinions that define the character above the tolerance Robinson (2001) then defining traits of tolerance namely: 1). Behave patient, $2)$. Be fair and objective to others who are different from ourselves in many ways, 3). Being receptive and appreciative of others and recognize the difference between others and ourselves.

From the definition of tolerance, can be obtained 2 conclusion that grain reflection tolerance and conclusions of the understanding of tolerance. Grain reflection obtained from an attitude of tolerance namely: 1). Peace is the goal, tolerance is the method, 2 ). Tolerance is open and receptive to the beauty of difference, 3). Tolerance reward individuals and perbedannya, remove the mask and tension disebebkan by ignorance, provides an opportunity to discover and remove the stigma caused by nationality, religion, and what is inherited, 4). Tolerance is respect each other through understanding, $5)$. The seeds of intolerance are fear and ignorance, 6). The seed of tolerance is love, showered with love and care, 7). If not love, then there is no tolerance, 8). Who knows how to appreciate the good in people and situations have tolerance, 9). Tolerance also means the ability to face a difficult situation, 10). Tolerance to the discomfort of life by letting go by, light weight, let others light, 11). Through understanding and openmindedness that is tolerant of other people 
treat others differently, and show tolerance, eventually evolving relationship.

In essence, the meaning of tolerance and respect for nature. The nature and respect must be shown by anyone to form a plurality in Indonesia, because tolerance is the simplest gesture, but have a positive impact to the integrity of the nation in general and the harmony of society in particular. From the definition above, the authors conclude that tolerance is a conscious attitude to accept, appreciate, objective / fair to all the actions, opinions, beliefs, understaffed and kelebiihan, similarities and differences, rules, values, ideas and behavior of others while not appropriate conscience is based on the humanitarian principles of justice, respect and equality to realize a peaceful and prosperous life, so if there is no tolerance will lead to unexpected conflicts. Implementation of this tolerance must be based on the attitude of tolerance toward others with regard to the principles held by itself that is like the principle described above. Therefore it is very clear that tolerance occurs and void because there are differences in principle and respect the differences or the principle of others without compromising his own principles. In other words, implementation is only on those aspects of the technical detail and not in matters of principle. Implementation of this tolerance must be based on the attitude of tolerance toward others with regard to the principles held by itself that is like the principle described above. Therefore it is very clear that tolerance occurs and void because there are differences in principle and respect the differences or the principle of others without compromising his own principles. In other words, implementation is only on those aspects of the technical detail and not in matters of principle. Implementation of this tolerance must be based on the attitude of tolerance toward others with regard to the principles held by itself that is like the principle described above. Therefore it is very clear that tolerance occurs and void because there are differences in principle and respect the differences or the principle of others without compromising his own principles. In other words, implementation is only on those aspects of the technical detail and not in matters of principle.

Tolerances are considered important for the Indonesian people in general and students in particular. As said by Amir Santoso, Professor of Social UI Rector Jayabaya, that the conflict in the community caused by many things and one of the reasons is the low tolerance between individuals and between groups. When a person or a group is more concerned with his ego and is not willing to understand the feelings and interests of others, then there was a conflict. Given the importance of tolerance, it should be applied in everyday life. This work is done in order to avoid conflicts caused by the lack of a sense of honor and respect for others. As proposed by the Mitchell et al. (2017) that what is needed in the community is not just looking for similarities and agreements are not easy to achieve, is the most important in the public air-Unity in Diversity is mutual understanding.

\section{Attitude Development Foundation for Tolerance}

Development of tolerance in SMK Nurul Ulum Plus is based on several things that could be considered the foundation in building tolerance. In this case SMK Plus Nurul Ulum using religious teachings and cultural foundation of the environment as a guideline for building tolerance. The use of religious and cultural teachings because both have mutually influential relationship with one another, as an example of a different culture gives a different understanding of the content of religion, and vice versa (Turner, 2006).

Religious teachings that are used as a foundation to build on tolerance is the teaching of Islam, Christianity and even Hindu-Buddhist. SMK Plus Nurul Ulum using various teachings of every religion to build tolerance because certainly every religion has a doctrine of mutual respect and respect for other faiths. In addition to religious teachings that are used to build tolerance in vocational Plus Nurul Ulum, he 
also uses culture as a foundation to build tolerance. Culture therein have values that make itself the very point of particular concern because it provides the media whose role is to build relationships that are indispensable for a cultural group in order that both the social system between cultures and social systems do not occur disintegration Parekh (2001), Part of the culture taken as a cornerstone in building a tolerant attitude is to take on the value of culture in the Jember Pendhalungan culture which is indeed a genuine culture of society Jember. Pendhalungan cultural values deemed able to create new characters for the community Jember themselves in particular, because of the value that is in the midst of indigenous communities like Pendhalungan to give effect to each individual to behave (Schwartz, 2013),

\section{Dogma}

Religion is one of a characteristic of universal human social life, with a sense that every society has ways of thinking and patterns of behavior that qualifies to be called a religion. Religion is all the rules that come from God that should be adhered to and carried out by human beings for the sake of human happiness itself both globally and in the hereafter (Sharp, 2012). In religion certainly have a good teachings to teach his community, in order to avoid negative attitudes that often happens in life. In general, religion teaches us to good things like tolerance, low self-esteem, humility and other good properties. With the exception of religious teachings that has properties as the orthodox religion, which she was referred to as a dogmatic religion. People are classified into orthodox religious teaching generally he has a deeply religious nature. Typically, people who have very religious nature such as this is characterized as a rigid, closed, intolerant, and did not want to change because it is part of piety in many ways that is equated with the irrational thinking and emotional disorders (Potgieter, Van der Walt, \& Wolhuter, 2014). Things like this indicates that the religion is a religious teachings putting himself and others. It should not be done because it generally does not allow religious teachings among humans hurt each other and mutually troublesome.

In Islam which is the religion of Allah revealed to Prophet Muhammad mengajarakan about much good one is morality. Every religion of Islam are required to pay attention to human values (Langmann, 2010). Each behavior must always be accompanied by the humility, introspection, and clever in bringing in the surrounding environment, especially a multicultural environment. Good attitude raised by someone in their daily life reflects that the person has a strong faith towards God (Yates, Davies, Gorely, Bull, \& Khunti, 2009). If a person tends to do a good deed, it can be ascertained that the person has a high level of faith. Likewise, if a person were more likely to do anything that is not good, then it is likely that the person has a low level of religiosity.

One manifestation of a good attitude in Islam is tolerance. Tolerance is an attitude that uphold the teachings of this religion, because Islam realizes that living creatures that inhabit the earth would not be the same one with the other. In accordance with the word of Allah in the Quran letter of AlHujurat verse 13 which reads "O mankind! We created you from a male and a female and made you nations and tribes that ye may know each other know. Verily the noblest among you is the most pious among you. Indeed, Allah is Knower know ". It is clear from the above verse bahwasannya indeed humans living in the world originally created men and women that is Adam and Eve. Then, of them gave birth to offspring different the offspring of Adam and Eve from different ethnic group, nation, race and language. However, the creation of human beings who have the difference is not too, differentiate its position by Allah SWT. Allah regards human beings have the same status and degree even though they are different. according to his word in the Qur'an letter of Al-Baqarah verse 136 which says "Say O believers. "We just believe in Allah and that which is revealed to us and what was revealed to Abraham, Isma'il, Isaac, Jacob, and the Tribes, and what 
was given to Moses and Jesus, and that given to the prophets from their Lord. We do not discriminate against one of them and we are Muslims submitted to Him ". race and language. However, the creation of human beings who have the difference is not too, differentiate its position by Allah SWT. Allah regards human beings have the same status and degree even though they are different. according to his word in the Qur'an letter of Al-Baqarah verse 136 which says "Say O believers. "We just believe in Allah and that which is revealed to us and what was revealed to Abraham, Isma'il, Isaac, Jacob, and the Tribes, and what was given to Moses and Jesus, and that given to the prophets from their Lord. We do not discriminate against one of them and we are Muslims submitted to Him ". race and language. However, the creation of human beings who have the difference is not too, differentiate its position by Allah SWT. Allah regards human beings have the same status and degree even though they are different. according to his word in the Qur'an suratAl-Baqarah verse 136 which says "Say O believers. "We just believe in Allah and that which is revealed to us and what was revealed to Abraham, Isma'il, Isaac, Jacob, and the Tribes, and what was given to Moses and Jesus, and that given to the prophets from their Lord. We do not discriminate against one of them and we are Muslims submitted to Him ". Allah regards human beings have the same status and degree even though they are different. according to his word in the Qur'an letter of Al-Baqarah verse 136 which says "Say O believers. "We just believe in Allah and that which is revealed to us and what was revealed to Abraham, Isma'il, Isaac, Jacob, and the Tribes, and what was given to Moses and Jesus, and that given to the prophets from their Lord. We do not discriminate against one of them and we are Muslims submitted to Him ". Allah regards human beings have the same status and degree even though they are different. according to his word in the Qur'an letter of Al-Baqarah verse 136 which says "Say O believers. "We just believe in Allah and that which is revealed to us and what was revealed to Abraham, Isma'il, Isaac, Jacob, and the Tribes, and what was given to Moses and Jesus, and that given to the prophets from their Lord. We do not discriminate against one of them and we are Muslims submitted to Him ". Jacob and his children and grandchildren and what was given to Moses and Jesus, and that given to the prophets from their Lord. We do not discriminate against one of them and we are Muslims submitted to Him ". Jacob and his children and grandchildren and what was given to Moses and Jesus, and that given to the prophets from their Lord. We do not discriminate against one of them and we are Muslims submitted to Him ".

From the above it is clear God's word bahwasannya indeed all humans, even not only human beings but animals and plants are all created differently by the almighty creator Allah. Our job as humans is good is to keep each other in order to keep the unity among differences. With the difference in the world above both in terms of race, nation, religion, race, language and even the opinion, in the teachings of Islam, Allah called on his community to have a mutually tolerant attitude toward others. This is in accordance with the word of Allah which contains the meaning of mutual respect and the respect of religious differences in the Quran letter of AlKafirun verses 1-6, which reads "Say O unbelievers. I will not worship what you worship. And ye are not worshipers of God that I worship. And I was never a worship what you worship, and you have not had also become worshipers of God that I worship. For you your religion and to me my religion ". In letter of Al-Kahf verse 29 also described "the truth from your Lord, then whoever wants to believe in, let him believe, and whosoever wants let him kafir infidel "Besides Allah also says about how to address the differences in the opinion contained in the Qur'an letter Yunus verse 41 , which reads" If they belie you then say. For me my job and you work, you separated yourself against what I'm doing, and I detached myself to what you do "

In addition to Islam, other religions such as Christianity, Hindu-Buddha also taught about tolerance, which is an attitude of tolerance is very important to implement in this world. In Christian teaching which, as 
already stated in the Book, John 13: 34-35 "new commandment I give unto you that ye love one another, just as I have loved you, that ye also love one another. By this shall all men know that ye are my disciples, if ye have love one to another ". In Romans 12:10 also call on people to look after each of tolerance among fellow "Be devoted to one another in brotherly love and mutual precede the salute"(Lembaga Sabda, n.d.), In Ephesians 4: 2 God also called "Be devoted to one another humility, gentleness, and patience. Show your love by helping each other" (Yewangoe, 2001).

No exception is also the HinduBuddhist teachings. This religion also mengajarakan about the importance of growing tolerance. Hindu-Buddhist religion aware of the existence of other religious beliefs and try to live in harmony, peace, and harmony with other faiths through a great tolerance towards the other teachings. Hinduism in creating tolerance among fellow contained in the concept of love that translate them into an understanding that all beings in this world are brothers, commonly known by the Hindus with the term Vasudaiva Kutumbhakam. When human beings hurt others then this is tantamount to hurting themselves, because the source of the feed atman rough body all beings are equal is derived from Brahman or Sang Hyang Widhi Wasa (God Almighty). Therefore all beings are brothers, then when someone gets kebahagaan, lainpun creatures are also entitled to the same happiness. This concept is known in Buddhist terms bhavantu Sukhitatta Sabbe Satta means may all beings be happy. The term implies that human beings should be the most perfect compared to other living beings always pray for the happiness of all beings in the world. two concepts that are equally uphold the teachings of compassion (in Javanese) are mutually animate each other in the flow of Siwa-Buddha This concept is known in Buddhist terms bhavantu Sukhitatta Sabbe Satta means may all beings be happy. The term implies that human beings should be the most perfect compared to other living beings always pray for the happiness of all beings in the world. two concepts that are equally uphold the teachings of compassion (in Javanese) are mutually animate each other in the flow of Siwa-Buddha This concept is known in Buddhist terms bhavantu Sukhitatta Sabbe Satta means may all beings be happy. The term implies that human beings should be the most perfect compared to other living beings always pray for the happiness of all beings in the world. two concepts that are equally uphold the teachings of compassion (in Javanese) are mutually animate each other in the flow of Siwa-Buddha (Swasgita, 2017),

It can be concluded that almost all religions in this world teach things as guidelines for the good of his community to life and religion. There is no one religion that teaches about the things that deviate from the truth, unless there is a person of a religion that hates another religion then he wants to destroy other religions in a way he recognizes as a community of faith that he wanted to destroy it. Of all the religions that have been described above, SMK Plus Nurul Ulum use it as a guide and a foundation for students to create and implement tolerance into daily life. Why the school did not only use the teachings of Islam, even though it has the basic boarding school? From interviews with the principal at the time of observation carried out, he explains: "Instead of the religious teachings of Islam we are taught to be tolerant with each other, so why do not we also use other religious teachings as a foundation to be tolerant. This was done so that boys and girls here getting steady to create tolerance, and so they know the that not only Islam can create tolerance.

\section{Cultural teachings}

Culture is a psychological structures through which individuals or groups of individuals to direct their behavior (Kitayama, 2002). Culture is not physical, and not an entity that is hidden. Culture is closely connected to the community, although the nature of the actual culture is abstract. But culture produces a form that is the form of objects created by man as a creature of culture, in the form of a pattern of behavior, language, equipment life, social organization, 
religion, art, and others, all of which was shown to help humans in the hold of the life of society. Harris (2001) defines culture is human knowledge that is believed to be true by the person concerned and covered and enveloped the feelings and emotions of human as well as a source for the assessment system is something that is good and bad, something valuable or not, something is clean or dirty, and so. This can happen because the culture was shrouded by moral values derived from moral values are a way of life and the ethos or ethical system in possess every human being. In essence, a culture has always inherited values, interpreted and implemented in line with the process of social change. Implementation of cultural values is a manifestation of the cultural and public legitimacy. The diversity of the noble values and the existence of cultural values which are owned by the Indonesian nation was instrumental in establishing the character of citizens, both related to the character of the private and public character.

Pendhalungan cultural value is the next cornerstone that they use to create the attitude of religious tolerance in schools. Hindaryatiningsih (2016) explains that every culture has its own cultural values as a basic virtue. In line with the above opinion, Musaddad (2018) also revealed that the integration of values such as cultural values it can dig tolerance students. Reflecting on it, Pendhalungan culture has virtues that could serve as the basis and provision landasar life by pupils and students of SMK Plus Nurul Ulum. Values that are born from a culture Pendhalungan such as solidarity, tolerance, mutual aid, social care, and so forth is something that is very important for students and senior high school students Nulum doing things such as acting, taking actions and decisions, as well as addressing a problem that will have implications for the creation of a harmonious life away from conflicts.

The real value is something abstract but can be used as guidelines in behaving. Humans without value will not be able to live a real life, because real humans have very close ties with the value that humans can achieve the goal of his life. Value is also an urgent matter for humans as serve as a set of beliefs that influence human attitudes and behavior. Male and female students of SMK Plus Nurul Ulum use as a filter value in the act. While there are of most students have eliminated the noble values rooted both in culture. However, one if they eliminate the noble values of a culture that has a moral message that is very good for their future.

Suparlan (2003) explain that cultural values are guidelines for people in a civilized, as can know that truth is the opposite of wrong, opponents of dirty clean, beautiful opposed to bad, and so on. In line with this Sartini (2009) said that the value of the local culture actually contains a wide range of philosophy, philosophy of life and ethics that can serve as guidelines for balancing the journey of life in this heterogeneous country. In accordance with the statement described above means that the value contained in the culture can deliver Pendhalungan especially humans in life to reach the goal of his life. No wonder students and students of SMK Plus Nurul Ulum choose Pendhalungan cultural values as an umbrella to two for their use as pajamas to be tolerant in school.

One Pendhalungan cultural values that serve as the hood in being tolerant is the value of tolerance. As explained previously associated with tolerance, bahwasannya tolerance is really needed in this era of mature today, especially for students and students of SMK Plus Nurul Ulum notabenenya is a student who has a historical background and social backgrounds differently so they can live in harmony and peace with friends who are within the scope of the same school. Besides that boys and girls can live in harmony and peace in the school environment, especially the orientation of cultural values Pendhalungan cultural values that serve as the foundation in being tolerant is to maintain relations with the public school close to him. Because the school is like a man who has a vertical relationship between each other. Humans who are in a vertical relationship will greatly feel dependent on others. Therefore, efforts to maintain good 
relations with its neighbors and each other is a matter which he considered very important in life.

The reason for choosing Pendhalungan especially its cultural values on the values of tolerance by male and female students of SMK Plus Nurul Ulum orphanage is they want to do not forget the roots of the origin itself. In addition, they also found his grandmother's ability to live in harmony and peace in Jember also armed with the tolerance values that exist in this Pendhalungan culture. So they decided to adopt a tolerance values of cultural heritage Pendhalungan Jember to serve as covering their hearts are tolerant of religious sects that exist. The ability of male and female students of SMK Plus Nurul Ulum orphanage that is driven by people who are very instrumental in the school as the board gugu and principals to have an attitude of mutual respect and respect (tolerance) towards each other in the school is a thing that can be said to be wise in addressing some problems in diversity. They bring an attitude of tolerance of religious and social tolerance in the midst of learning is something that is not easy to do by their age, which most kids their age are still with happy swim dive into the ocean teenage years are filled with frenetic without considering others that is around. So that students their age rarely ignore social attitudes that have an impact in life.

\section{Strategies Attitudes Tolerance}

SMK Plus Nurul Ulum is a private school that is now creating and developing tolerance in the environment. Tolerance developed by this school is a social and religious tolerance. Seeing the fact that said that in the body of SMK Plus Nurul Ulum consists of students from different social circumstances and the different religious wing. Furthermore, see the state of the environment around the school also has social circumstances differ, the society of the middle classes and above and the medium then the school has decided to create and float tolerance towards each other in various ways so that people are not the same as others are not discriminated against and marginalized.
Various strategies in creating an attitude of tolerance developed by the middle of this school assisted by the principal, the teacher and the student council siswinya. With the existence of this strategy is expected to create and float tolerance between people. As an example, in this school there is a program called La Tahzan, in which the program is a new program created by OSIS SMK Plus Nurul Ulum. This program has a vision of "Solidarity in Diversity Frame". According to an interview with one of the members of the council namely SMK Plus Nurul Ulum Siti Khotimah "La Tahzan Program is a program of solidarity, but this time that was initially just solidarity evolved into a spirit of tolerance. Their vision of the spirit of tolerance in La Tahzan program is inspired when we see victims of the earthquake in Lombok. They did not one of race, ethnicity, language with us as a Javanese. But what's wrong with us as human beings turu also help those who are experiencing the devastating disaster. So the vision of solidarity and tolerance in $\mathrm{La}$ Tahzan this program we merge into one. Solidarity is realized that the way to help lighten their load as provide assistance in the form of cash, used clothes and so on. Then we realize tolerance attitude towards them is by helping them regardless of origin or the origin and background of their lives. We do not care whether they are rich, poor, Christian, Hindu or Buddhist, sasak, Java or not.

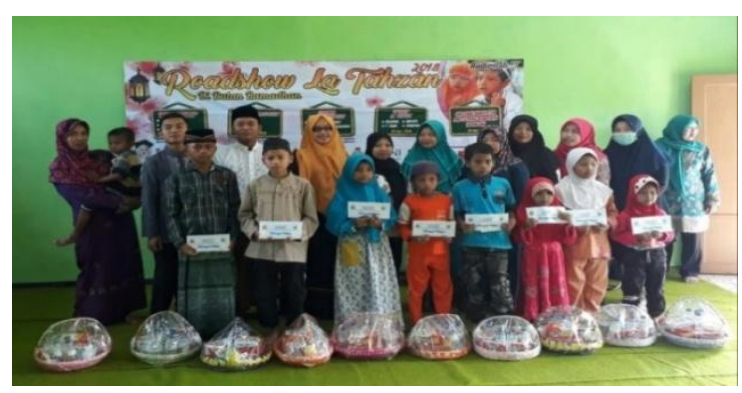

Figure 1. The form of solidarity to orphans around SMK Plus Nurul Ulum.

As we know that embody tolerance is not easy. Tolerance is an attitude that is difficult to apply in the community. Certain group of people want to show their power and abilities in the form of conflict. Usually they are reluctant to solve problems by consensus or democracy. The strategy that is owned by SMK Plus Nurul Ulum is a strategy that is 
appropriate to be done in creating tolerance. The school is aware that we belong together, realizing that the difference is not an issue to unite and work together and realize that we are guided by Pancasila.

\section{CONCLUSION AND RECOMMENDATION}

SMK Plus Nurul Ulum is a school located in one of the village in the district of Jember Panti. This school is a school-based Islamic boarding school. SMK Plus Nurul Ulum stand and thrive under the auspices of the foundation Nurul Ulum At-Tawheed led by Kyai. SMK Plus Nurul Ulum is a private school that is able to create an attitude of tolerance towards their fellow human beings. Tolerance created by this school in the religion based on the teachings agam teachings of Islam, Christianity and HinduBuddhist. The use of a wide range of religious teachings intended to create tolerance for every religion must have a good teaching to be taken from his people. And proved when taking some of the teachings contained in the scriptures of each religion in it found a wide variety of teachings of kindness, especially the attitude of tolerance and love of neighbor.

Furthermore, tolerance built in vocational Nurul Ulum also based on cultural values Pendhalungan Jember. Pendhalungan cultural values Jember believed to dijadikannya senbagai cornerstone in creating a culture of tolerance for Jember Pendhalungan have social values, especially the value of tolerance that should be preserved until now in particular to Jember society itself. Strategies in creating tolerance in vocational Nurul Ulum is to establish a special program, namely La Tahzan, which the program has multiple functions namely as a means of solidarity and tolerance. A wide variety of activities have been generated by this program to succeed the vision contained in it namely solidarity and tolerance.

\section{REFERENCES}

Almond, B. (2010). Education for tolerance: Cultural difference and family values.
Journal of Moral Education, 39(2), 131-143.

Endang, B. (2009). Mengambangkan Sikap Toleransi dan Kebersamaan di Kalangan Siswa. Jurnal Visi Ilmu Pendidikan, 1(2), 89-105.

Fiala, A. (2005). Tolerance and the ethical life. A\&C Black.

Harris, M. (2001). Cultural materialism: The struggle for a science of culture. AltaMira Press.

Hindaryatiningsih, N. (2016). Process Model Inheritance Value-value of Local Culture in Society Tradition Buton. Journal of Social Sciences and Humanities, 18(2), 108-115.

IDNTimes. (2018). Ini Enam Peristiwa Intoleran yang Pernah Terjadi di Indonesia. Retrieved from IDNTimes website:

https://www.idntimes.com/news/indon esia/linda/5-kejadian-penyeranganrumah-ibadah-di-indonesia/full

Kitayama, S. (2002). Culture and basic psychological processes-toward a system view of culture: Comment on Oyserman et al.(2002).

Kompas.com. Penelitian: Kasus Intoleransi Masih Sering Terjadi di Jateng Selama 2017. , (2018).

Langmann, E. (2010). Welcoming difference at the limit of tolerance education. Philosophy of Education Archive, 337-345.

Lembaga Sabda. (n.d.). Alkitab Sabda.

Mitchell, R., Boye, B., O’brien, R., Malik, A., Tian, K., Parker, V., ... Chiang, V. (2017). Balancing cognitive diversity and mutual understanding in multidisciplinary teams. Health Care Management Review, 42(1), 42-52.

Musaddad, A. A. (2018). The Reinforcement of Dharma Gita Bali Values in Historical Learning to Improve 
Students Tollerance Attitude. International Journal of Multicultural and Multireligious Understanding, $5(2)$.

Parekh, B. (2001). Rethinking multiculturalism: Cultural diversity and political theory. Ethnicities, 1(1), 109-115.

Potgieter, F. J., Van der Walt, J. L., \& Wolhuter, C. C. (2014). Towards understanding (religious)(in) tolerance in education. HTS Teologiese Studies/Theological Studies, 70(3).

Powell, R. (2002). Religion, Tolerance and Intolerance: Views From Across the Dicipliness. Journal of Philosophy Tolerance Background, 13, 34-63.

Robinson, J. (2001). The social-ization of tolerance. In M. Augoustinos \& K.J. Reynolds (EDS.) Understanding prejudice, racism, and social conflict. London: Sage.

Sartini, N. W. (2009). Mengali Nilai Kearifan Lokal Budaya Jawa Lewat Ungkapan (Bebasan,Saloka dan Paribasa). Jurnal Ilmiah Bahasa Dan Sastra, v(1), 2837.

Schwartz, S. H. (2013). Societal Value Culture: Latent and Dynamic. Journal of Cross-Cultural Psychology, 45(1), 42-46.

Sharp, D. R. (2012). Sociology of religion. The Encyclopedia of Christian Civilization.

Simarmata. (2017). Indonesia Zamrud Toleransi. Jakarta: PSIK-Indonesia.

Suparlan, P. (2003). Bhineka Tunggal Ika: Keanekaragaman Suku Bangsa atau Kebudayaan. Jurnal Antropologi Indonesia, 72(1), 29-37.

Swasgita, I. P. H. Y. (2017). Realisasi Toleransi Antar Umat Hindu dan Buddha di Pura Pusering Jagat Panca Tirta Desa Pakaraman Kembang Merta Desa Candikuning Kecamatan
Baturiti Kabupaten Tabanan. Jurnal Penelitian Agama Hindu, 1(2), 263269.

Turnbull, J., Lea, D., Parkinson, D., Phillips, P., Francis, B., Webb, S., ... Ashby, M. (2010). Oxford advanced learner's dictionary. International Student's Edition.

Turner, B. S. (2006). Religion. Journal of Theory, Culture and Society, 23(2-3).

Williams, M. (2015). A New Definiton Of Tolerance. Journal of Issues in Religion and Psychotherapy, 37(1).

Witenberg, R. T. (2007). The moral dimension of children's and adolescents' conceptualisation of tolerance to human diversity. Journal Of Moral Education, 36(4), 433-451.

Yates, T., Davies, M., Gorely, T., Bull, F., \& Khunti, K. (2009). Effectiveness of a pragmatic education program designed to promote walking activity in individuals with impaired glucose tolerance: A randomized controlled trial. Diabetes Care, 32(8), 14041410.

Yewangoe, A. A. (2001). Agama dan kerukunan. BPK Gunung Mulia. 